Antidumping Reform, Trade Policy

Flexibility, and Compensation

Alexander Roitinger

August 2002 D iscussion paper no. 2002-18 
Editor:

Publisher:

Electronic Publication:
Prof. Jörg Baumberger

University of St. G allen

Department of Economics

Bodanstr. 1

CH-9000 St. Gallen

Phone ++41712242241

Fax ++41712242885

Email_joerg.baumberger@unisg.ch

Forschungsgemeinschaft für $\mathrm{N}$ ationalökonomie an der U niversität St. Gallen

Dufourstrasse 48

$\mathrm{CH}-9000$ St. Gallen

Phone $\quad++41712242300$

Fax $\quad++41712242646$

www.fgn.unisg.ch/public/public.htm 


\title{
Antidumping Reform, Trade Policy Flexibility, and Compensation ${ }^{1}$
}

\author{
Alexander Roitinger
}

Author's address: Alexander Roitinger, lic.oec.

SIAW -HSG

Dufourstrasse 48

$\mathrm{CH}-9000$ St. Gallen

Tel. $\quad++41712242578$

Fax $\quad++41712242298$

Email alexander.roitinger@unisg.ch

W ebsite www.siaw.unisg.ch

1 The author is indebted to Heinz Hauser for valuable suggestions, and to Juliane Kokott, Thomas Liebig, Martin N ettesheim, U we $\mathrm{W}$ alz, and Thomas A. Zimmermann for comments on various drafts. 


\section{Abstract}

Antidumping has become the dominant instrument for temporarily restricting imports. There is need for concern, as it represents a particularly distorting trade policy measure. Many observers have made suggestions on how to improve the current situation. These suggestions aim at restraining antidumping by reducing the number of circumstances where it may be applied. In other words, they envisage higher prerequisites for the use of antidumping. Yet, higher prerequisites for temporary import restrictions impair the government's trade policy flexibility. This article assumes that governments are not ready to sacrifice such flexibility by means of an international trade agreement. Therefore, suggestions that merely intend to raise the prerequisites for the use of antidumping are difficult to realise. W e propose an alternative solution for antidumping reform. It considers abolishing antidumping and introducing a revised safeguard clause. This clause would permit temporary import restrictions without any prerequisites, but would make these restrictions dependent on full compensation for affected trading partners. In contrast to existing suggestions for reform, this alternative solution preserves the trade policy flexibility provided by the current antidumping regime, but effectively restrains protectionist behaviour.

\section{Keywords}

Antidumping, Safeguard Clause, Compensation

\section{JEL Classification}

$F 02, F 13, K 33$ 


\section{Introduction}

Antidumping has become the dominant instrument used by both developed and developing countries for temporarily restricting imports. There is need for concern, as it represents a particularly distorting trade policy measure. Despite popular claims to the contrary, antidumping has lost its connection with anticompetitive foreign practices and is at the moment primarily applied to protect ailing industries. Many observers have made suggestions on how to improve the current situation. These suggestions aim at restraining antidumping by reducing the number of circumstances where it may be applied. In other words, they envisage higher prerequisites for the use of antidumping. Attempts to raise the prerequisites were already undertaken at the occasion of the Uruguay Round. However, these attempts clearly failed.

Higher prerequisites for temporary import restrictions impair the government's trade policy flexibility. Trade policy flexibility is defined as the ability to decide on when to restrict imports. This article assumes that governments are not ready to sacrifice such flexibility by means of an international trade agreement. Therefore, suggestions that merely intend to raise the prerequisites for the use of antidumping are difficult to realise.

We propose an alternative solution for antidumping reform. It considers abolishing antidumping and introducing a revised safeguard clause. The rare instances of anticompetitive behaviour by foreign exporters could be handled under national antitrust policy. The revised safeguard clause would permit temporary import restrictions without any prerequisites, but would make these restrictions dependent on full compensation for affected trading partners. In contrast to existing suggestions for reform, this alternative solution preserves the trade policy flexibility provided by the current antidumping regime, but effectively restrains protectionist behaviour.

The next section briefly traces developments in the use of antidumping against the background of the new regime concluded in the context of the Uruguay Round. As well, the main problems of antidumping are identified. Section three presents existing suggestions for reform and questions their feasibility. The fourth section elaborates on the characteristics of the alternative solution for antidumping reform. Section five proposes to abolish antidumping and to introduce a revised safeguard clause as the appropriate way for the implementation of the alternative solution. Furthermore, implications for the role of the WTO dispute settlement are discussed. 


\section{The extensive use of antidumping}

\section{A. Increasing popularity after the Uruguay Round}

The popularity of antidumping as an instrument for import restrictions is not surprising, given its broad applicability since the adoption of the Tokyo Round Antidumping Code in 1979. Both the inclusion of sales below cost for the definition of "less than fair value" and the abolition of the requirement that dumped imports be demonstrably the principal cause of material injury, have opened a door for contingent protection that is without precedent in the history of multilateral trade liberalisation. Today, the requirements for the determination of dumping are extremely low. Furthermore, since dumping has always been judged to represent unfair behaviour, countermeasures do not come along with the provision of compensation, in contrast to many other measures of contingent protection.

Figure 1 sheds light on the world-wide use of antidumping since the early days of the Uruguay Round. Between 1987 and 2001, more than 3300 investigations were initiated, of which 1700 resulted in definitive measures. Despite the new Agreement on Antidumping, which nurtured some positive expectations, antidumping activity became more intense after the conclusion of the Round: the average annual number of investigations increased from 198 (between 1987 and 1994) to 264 (between 1995 and 2001), and the respective number for definitive measures rose from 88 to 152 . This surge can be partly attributed to the fact that the number of countries applying antidumping has risen substantially over time. In 1987, six countries (or customs unions) initiated investigations, ${ }^{\text {G }}$ but 23 did so in 2001. Mexico and Korea were the only nonindustrialised countries applying antidumping in 1987, reporting 16 percent of all investigations. In contrast, the developing world initiated 65 percent of all investigations in the latest reporting period.

See Blonigen and Prusa (2001).

Agreement on the Implementation of Article VI of the GATTT from 1994.

Finland is not counted for reasons of comparison (EC membership since 1.1.1995).

This period covers 1 July to 31 December 2001. See Bridges Weekly Trade News Digest, Vol. 6, No. 15, 23 April 2002. Vermulst (1997) makes suggestions for the adoption and implementation of antidumping law in developing countries. 


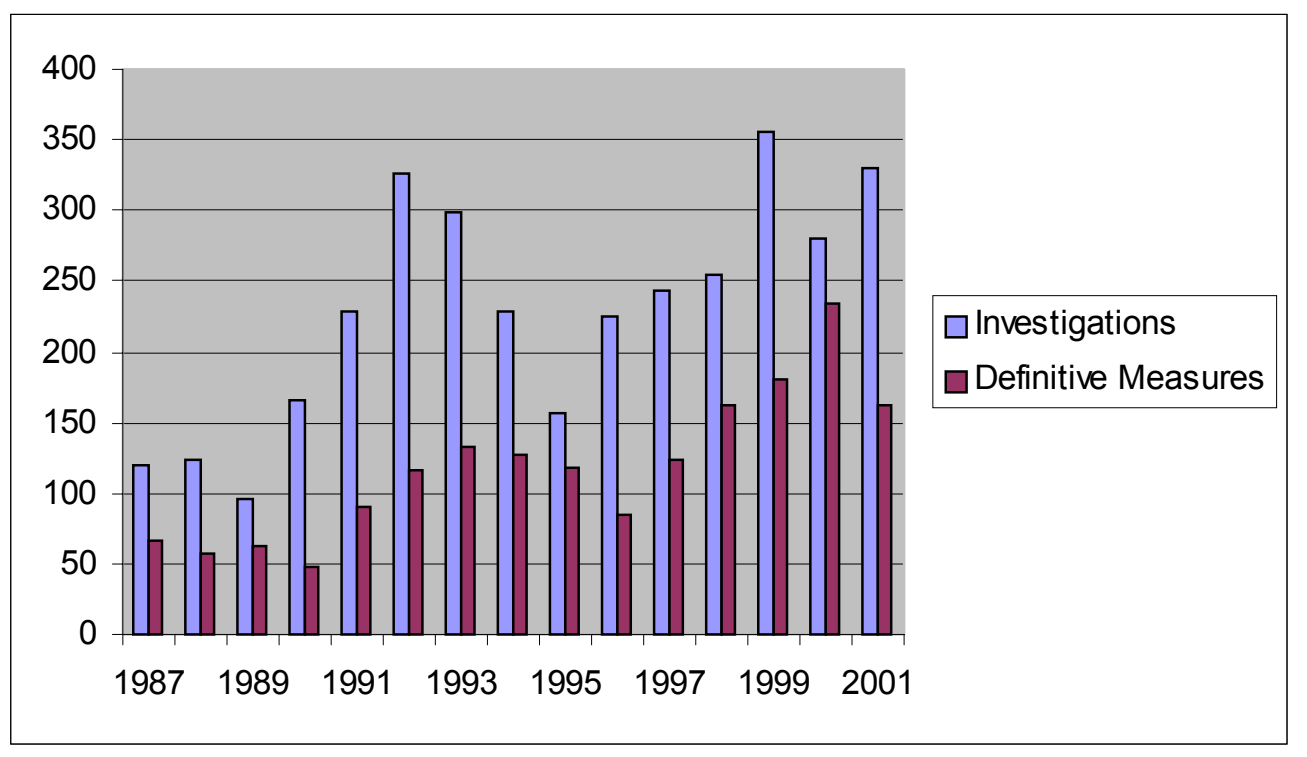

Figure 1: Antidumping investigations and definitive measures

These numbers tell us something about the relative attractiveness of antidumping over time. Likewise, it is helpful to compare them with the respective results of other instruments offering contingent protection. The most obvious candidate for such a comparison is the safeguard clause, in accordance with Article XIX GATT and the Agreement on Safeguards. Between 1995 and 2001, a total of 68 investigations were initiated and 28 definitive measures imposed. ${ }^{\text {This }}$ translates into average annual numbers of ten and four, respectively, which are higher than the numbers for the period between 1987 and $1994{ }^{1}$ Based on this simple comparison, one cannot completely reject the claim that antidumping has replaced some safeguard clause action over the years. However, more convincing is the suggestion that antidumping has been used in addition to it.

The rising popularity of antidumping after the Uruguay Round must be a surprise for those who expected that the new Agreement on Antidumping would reduce its attractiveness. ${ }^{0}$ This expectation was caused by apparent efforts to introduce higher prerequisites for the use of antidumping into the Agreement. ${ }^{1}$ For example, Article 5:8 provides for a "de minimis"-rule, which states that " $[\mathrm{t}]$ here shall be immediate termination [of investigation] in cases where the authorities de-

6 The data comes from the Homepage of the WTO (see Trade Topics - Antidumping) and from Miranda, Torres and Ruiz (1998).

7 See the reports of the Committee on Safeguards to the Council for Trade in Goods, dated 23 November 2000 and 31 October 2001, Documents No. G/L/409 and G/L/494, respectively. The reporting period ended at 29 October 2001.

8 The WTO (1995) counts 18 cases resulting in protection between 1 January 1987 and 30 November 1993. Finger (1998) provides a detailed view on the evolution of the safeguard clause.

9 In an article from 1995, Horlick and Shea expected "a reversal of a tendency to make the imposition of antidumping easier" (p. 5). 
termine that the margin of dumping is de minimis [i.e. less than two percent], or that the volume of dumped imports, actual or potential, or the injury, is negligible." Another rise of prerequisites seemed to come from reduced discretion with respect to a variety of technical methodologies. Article 2:4 requires to make a "fair comparison" of prices when calculating the dumping margin. In particular, the comparison must be either on an average-to-average or on a transaction-totransaction basis.

In addition to its rising popularity, the landscape of antidumping use has changed significantly in other ways as well. The traditional users of antidumping, namely Australia, Canada, the European Communities (EC), Mexico, New Zealand and the United States (US), are increasingly targeted themselves by antidumping measures. Figures 2 (a) and (b) are drawn for antidumping investigations and definitive measures, respectively. For each traditional user, the bars indicate what may be called the "reciprocity ratio". This ratio is calculated by dividing the number of cases where the country is confronted with foreign antidumping by the number of cases where the country applies antidumping itself. High reciprocity ratios support the notion that antidumping has degenerated into some sort of prisoner's dilemma, where all users are necessarily made worse off compared to the situation without any antidumping.

10 A comprehensive overview of the Uruguay Round Agreement on Antidumping and its major modifications is provided by Horlick and Shea (1995). See also Krishna (1997) and Niels (2000). 

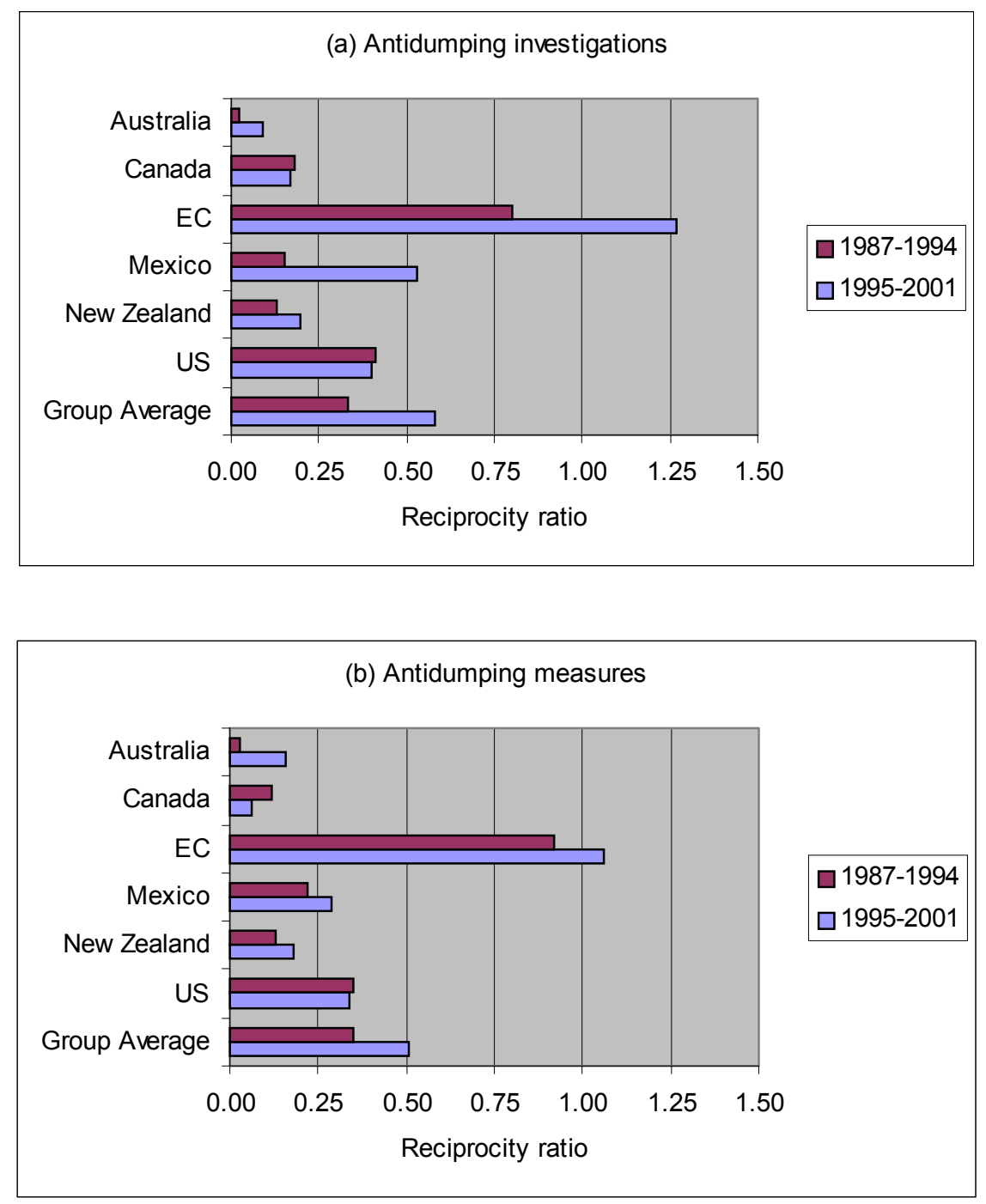

Figure 2(a) and (b): Reciprocity ratios for traditional users

Comparing the periods of 1987-1994 and 1995-2001, most reciprocity ratios increased substantially. The rise is particularly strong for investigations, where the group average increased from 0.33 to 0.58 . The latter ratio means that, for every ten antidumping investigations initiated by themselves, traditional antidumping users are confronted with almost six foreign investigations. The situation is most pronounced for the EC, which have a reciprocity ratio well above one, and which are therefore affected by foreign investigations more often than conducting investigations themselves. It is conceivable that the increasing risk of becoming a target of reciprocal antidumping action begins to have measurable effects on the decision by industries of which foreign countries to name in antidumping petitions $\frac{1}{1}$ This is likely to reinforce selective antidumping

11 Calculations by the author, based on data from the Homepage of the WTO (see Trade Topics - Antidumping) and from Miranda, Torres and Ruiz (1998).

12 See Blonigen and Bown (2001). 
patterns, which are characterised by the tendency to target primarily weak countries unable to retaliate, instead of those which are most capable of dumping their exports.

\section{B. The problems of antidumping}

The trouble with the extensive use of antidumping is at least threefold. First, there is no economic rationale for antidumping action as long as dumped imports are not based on predatory intent. ${ }^{3}$ Such an intent is difficult to prove, but can easily be precluded in most cases. For example, Shin (1998) analyses 282 antidumping investigations in the US between 1980 and 1989 with

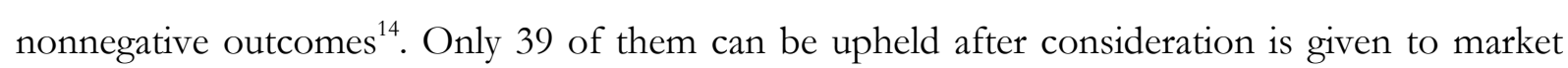
structures that are simply irreconcilable with monopolistic behaviour. Apart from the fact that they represent only 14 percent of the sample, these cases would have to be examined further, seeking for example for the existence of market entry barriers as another necessary precondition for successful predatory practice. Messerlin (2001) does a similar exercise as Shin, but for the European Communities. He concludes that only two percent of 461 cases initiated between 1980 and 1997 are candidates for closer examination on predation grounds.

Second, there is the substantial evidence that antidumping is used even in the absence of any dumping. The Agreement on Antidumping and national antidumping laws make it possible to deviate strongly from economically reasonable calculation methods. Lindsey (2000) concludes that current US law is unable of reliably identifying either price discrimination or sales below cost. Hindley (1993) reasons that European antidumping law "is more appropriately associated with Kafka than with fairness." He particularly points to special "tricks" with averages that help to establish positive dumping margins.

Third, current antidumping practice can create a paradox situation: although it is ultimately intended to secure competition at home, there are strong indications that antidumping promotes collusive agreements between firms. ${ }^{6}$ Since it is merely the threat of an antidumping investigation that is in many instances responsible for such an agreement, the numbers presented above clearly underestimate the negative implications of the current policy.

13 See e.g. Corden (1997). A more comprehensive justification for antidumping is given by Stewart (1991).

14 Nonnegative outcomes consist of the cases in which antidumping was eventually imposed and the cases that were suspended or terminated. It is not impossible that suspended or terminated cases represent instances of predatory dumping.

15 In contrast to Shin, Messerlin's original dataset includes the cases with negative findings.

16 See Prusa (1992). Taylor (2001) provides anecdotal evidence for collusion, but at the same time rejects the claim that withdrawn antidumping petitions are generally a signal of collusive action. For various strategic responses to the presence of antidumping law, see Blonigen and Prusa (2001) or Pauwels, Vandenbussche and Weverbergh (2001). 
Summarising the findings thus far, antidumping surged globally in the last two decades, but it lost its connection with "unfair trade", whatever the precise meaning of unfair is. Therefore, it has become an ordinary trade policy instrument used to protect ailing industries. Economic theory teaches us about the consequences of such a trade distortion, and there is no doubt that the welfare loss by far exceeds the effects of definitive antidumping measures. Prusa (1999) calculates that antidumping duties cause the value of imports to fall by 30 to 50 percent on average, but that trade declines by almost as much in settled cases. Furthermore, even negative findings of the responsible authorities cannot avoid a decrease in trade by 15 to 20 percent. Gallaway, Blonigen and Flynn (1999) estimate the combined welfare loss of US antidumping and countervailing measures for the domestic economy to be almost four billion USD in 1993 alone. This amount does not include the effects of actions that have been threatened, but not implemented. However, whereas antidumping is condemned by most economists, the public does not seem to have recognised its negative impact on welfare. In contrast, the argument of unfair trade, questionable as it might be, still meets with high response in the public debate of industrialised countries.

\section{Existing suggestions for reform}

\section{A. General remarks}

Due to the global prevalence of antidumping and its danger for a more liberal world trading order, many ideas have been brought forward on how to improve the current situation. Most of these suggestions intend to make the use of antidumping less attractive. Additionally, some envisage a more attractive safeguard clause. The consideration of the safeguard clause is explained by the hope that the clause might be able to (gradually) replace antidumping provisions. ${ }^{\square}$

Arguably, the attractiveness of an instrument for import restrictions is negatively correlated with the respective level of both "prerequisites" and "compensation". The prerequisites of an instrument are high if it can be used only under a few predefined circumstances. High prerequisites effectively limit the ability of the government to decide on when to restrict imports, thereby reducing trade policy flexibility. On the other hand, low prerequisites barely impair trade policy flexibility.

The compensation dimension, on the other hand, states when and how affected trading partners are reimbursed for the loss incurred by the import restriction. Compensation is limited to foreign trading partners, represented by their governments. In principle, it could be in pecuniary form,

17 The strong connection between these two directions is confirmed by requests to assign the task of reforming the Agreements on Antidumping and on Safeguards to the same negotiating group. See Messerlin and Tharakan (1999). 
but the multilateral trading order tends to prefer the provision of improved market access in sectors unrelated to the contingent protection. $\square^{18}$ Consequently, full compensation should be understood as trade-liberalising measures that maintain the balance and the level of concessions and other obligations existing among multilateral trading partners before contingent protection was introduced. It must not set in later than the import restriction itself. Obviously, some advanced procedures are required in order to calculate the damages owed under a full compensation rule. Yet, such a calculation is a problem that is actually known how to deal with since the conclusion of the GATT in $1947 \square^{19}$ Both the safeguard clause and the renegotiation clause of Article XXVIII GATT incorporate mechanisms that help to find a new balance after a government has expressed its desire to deviate from initial concessions.

Figure 3 depicts the attractiveness of antidumping and the safeguard clause according to the current regime. It uses prerequisites and compensation in order to span a plane by means of two axes. The circles show where the two instruments for temporary import restrictions would have to be localised. Obviously, antidumping is more attractive than the safeguard clause in respect to both prerequisites and compensation:

18 This is most obvious in Article 8:1 of the Agreement on Safeguards, which explicitly uses the term "trade compensation".

19 See Sykes (2000). 


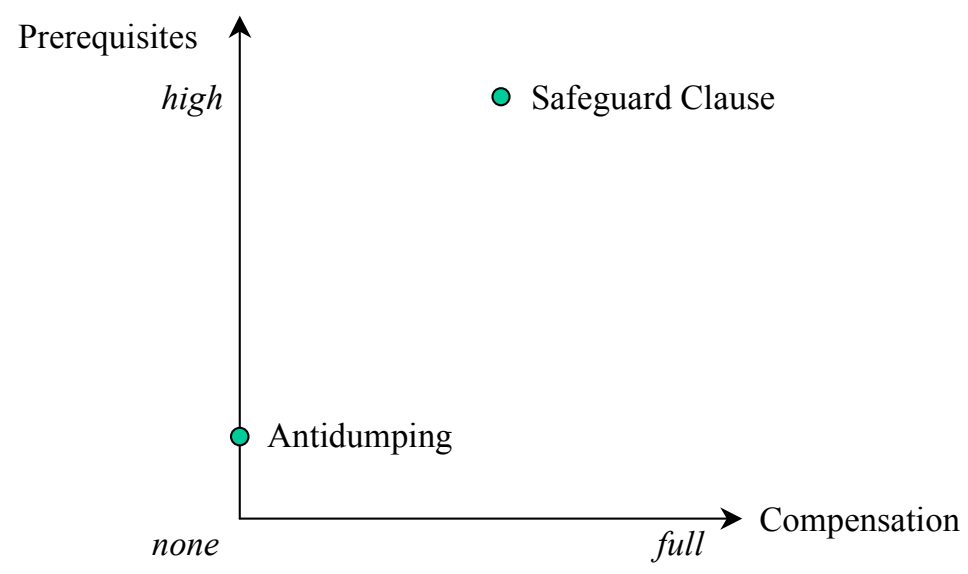

Figure 3: Localising antidumping and the safeguard clause

Antidumping requires no compensation, since it is allegedly based on unfair trade. The use of the safeguard clause comes along with full compensation in many cases, but there are exceptions that should be noted. No compensation is owed for a three-year time period in case of an absolute increase in imports. ${ }^{20}$ On average, a medium level of compensation can therefore be expected.

With regard to prerequisites, the classification becomes somewhat more burdensome. According to the Agreement on Safeguards, measures may be applied if imports enter the country "[...] in such increased quantities, absolute or relative to domestic production, and under conditions as to cause or threaten to cause serious injury to domestic industry [...]. 22] In addition, Article XIX:1 GATT requires that the increase in imports is a result of both unforeseen developments and ongoing liberalisation. 2 Antidumping is formally restricted to dumping that "[...] causes or threatens material injury to an established industry [...] or materially retards the establishment of a domestic industry. ${ }^{23}$ It is difficult to judge the exact severity of these prerequisites and to uncover properly the respective differences between safeguard clause and antidumping. ${ }^{24}$ However, some observations are straightforward. First, the use of a more stringent injury standard (serious instead of material) is an obvious way of complicating access to the safeguard clause relative to antidumping. Second, the safeguard clause requires an increase in the import level, unforeseen developments, and a connection with ongoing liberalisation. All these prerequisites cannot be found in the antidumping provisions. Third, only antidumping has a price component, as it requires that imports are dumped. However, this prerequisite can easily be construed. In short, whereas no

20 In Article 8:3 of the Agreement on Safeguards, the right of negatively affected trading partners to suspend equivalent concessions is disabled for a three-year time period in case of an absolute increase in imports. We infer from this rule that no compensation can be expected either.

21 Article 2:1 of the Agreement on Safeguards.

22 The relationship between Article XIX GATT and the Agreement on Safeguards is discussed later in this section.

23 Article VI:1 GAT'T. 
attempt has been made here to precisely qualify the scale of prerequisites, the following conclusion is drawn: the level of prerequisites is substantially higher for the safeguard clause than for antidumping. ${ }^{25}$

\section{B. Reducing the attractiveness of antidumping}

With this classification in mind, existing suggestions for reform can now be analysed. As already mentioned, they can be divided into two categories. The first category consists of proposals that would make antidumping less attractive. The respective suggestions in the literature are mostly based on the conviction that antidumping has been abused in the past, but that the concept as such is nonetheless a legitimate element of the world trading order. Consequently, they are not about making its use more expensive by requiring some kind of compensation. ${ }^{2}$ Instead, they intend to raise the level of prerequisites. This can generally be done by enriching the Agreement on Antidumping with rules that are better based on sound economics. Major suggestions in this respect focus on the calculation of the dumping margin, on the inclusion of market structure analysis, and on the determination of injury.

To begin with, the enormous leeway in construing the dumping margin could be reduced. ${ }^{7}$ The margin is calculated by subtracting the export price from "normal value", which is the price for the like product when destined for consumption in the exporter's home country. It was recommended that when there are few or no domestic sales, normal value should be calculated based on the price of exports to the largest third market. The suggestion intends to provide the most reliable data, and more importantly, to avoid an arbitrary estimation of the exporter's production costs for the determination of normal value. Furthermore, when there are sufficient domestic sales, their prices should be observed across the whole business cycle, and low prices should not be excluded from calculating averages. This in fact counters the popular "zeroing method", which assigns zero values to negative dumping margins. ${ }^{28}$ A related proposal is to eliminate the

24 A comprehensive analysis is offered by Jackson (1997).

25 Support for this conclusion also comes from WTO case law. As Didier (2001) notes, recent decisions have both "watered down" the requirement of material injury and "emptied" the need for causality between dumping and injury (p. 34).

26 At first sight, Bown (2002) is a notable exception. He suggests that antidumping users deposit all revenue into an escrow account. The distribution of these funds would then be determined by the WTO, based on the statutory acceptability of the antidumping measure imposed. Though this suggestion seems to combine antidumping with compensation, it in fact does not. Only those cases that are decided by the Dispute Settlement Body (DSB) in favour of the target would lead to financial refunds. Compared to the overall number of antidumping cases, these incidents would be extremely rare - given that the substantive rules on antidumping remain the same as they currently are. A true impact on the antidumping regime would therefore have to come again from raising the prerequisites.

27 See Miranda, Torres and Ruiz (1998) for a concise discussion.

28 Only recently, the zeroing method applied by both the US and the EC was successfully challenged in two WTO disputes. See EC - Antidumping Duties on Imports of Cotton-type Bed Linen From India (WT/DS141) and US - Imposi- 
exception to the requirement that price comparisons must be either on an average-to-average or on a transaction-to-transaction basis $\stackrel{29}{\square}$ Overall, the construction of the dumping margin should therefore be guided by a fair comparison of export price and normal value. For this to be the case, it seems rather natural to suggest that identical products be used whenever possible, and that they not be taken from different stages of the distribution chain

More sound economics would also be applied if antidumping measures were made dependent on positive findings that dumped imports have a negative impact on market structure. Such an impact can be ruled out categorically whenever the relevant market shows a low level of concentration, since this indicates that the industry under investigation does not have positive economies of scale. Inspired by this idea is the suggestion that the "de minimis" rule ought to be expanded. ${ }^{2}$ Moreover, the rule should be based on market shares instead of import shares. The fear of monopolising tendencies is unfounded as long as investigated imports are small relative to overall market size.

The analysis of market structure draws heavily on antitrust law. It was consequently proposed that antidumping could generally be guided by antitrust principles, thereby making predatory intent a necessary prerequisite for antidumping action. ${ }^{3}$ In the case that the exporter under investigation does not dispose of a protected home market, it is difficult to imagine that predatory intent can exist. ${ }^{3}$ Therefore, the antidumping procedure could be supplemented by an investigation into the contestability of the exporter's home market. Such an investigation might be guided by an international competition agreement, which provides for a harmonisation of national competition rules. ${ }^{.5}$ Less ambitious (and more realistic) would be the application of "positive comity".

tion of Antidumping Measures on Stainless Steel Plate in Coils and Stainless Steel Sheet and Strip from Korea (WT/DS179). For an in-depth analysis see Kim (2002).

29 See Messerlin (2000). The exception is provided for in Article 2:4:2 of the Agreement on Antidumping and concerns a "pattern of export prices which differ significantly among different purchasers, regions or time periods."

30 Didier (2001) provides very detailed suggestions in this respect.

31 See Shin (1998).

32 See Messerlin (2000).

33 See, among others, Tharakan (1999), Trebilcock and Howse (1999), Lipstein (1997), or Palmeter (1996). Messerlin (1994) discusses problems resulting from conceptual inconsistencies between antidumping and antitrust principles. In this context see also Boscheck (2001).

34 A protected home market would allow the exporter to cross-subsidise lower prices in export markets. Furthermore, parallel imports could be warded off.

35 See Morgan (1996). Hauser and Schöne (1994) doubt the need for harmonised competition rules, since dumping with predatory intent can be sufficiently countered by national antitrust rules (according to the "effects doctrine"). However, they recognise that an international competition agreement might be a precondition in order to get the political support for the restraining of antidumping. Hoekman (1998) studies a variety of preferential trading agreements, some of which have introduced common antitrust principles and/or abolished antidumping among members. He concludes that the economic and empirical basis for the linkage between these two steps is questionable. Mavroidis and Van Siclen (1997) discuss work needed in order to apply the WTO dispute settlement to an international competition agreement. 
In this case, the competition authorities in the exporter's home country would favourably treat the request from abroad to conduct an investigation into the exporter's domestic base. ${ }^{36}$

Economic expertise could be applied more diligently when determining injury. Hoekman and Leidy (1989) have long been suggesting that the number of admissible indicators for injury be reduced dramatically, and that the threat of injury alone should not be a cause for antidumping action. Furthermore, demonstrating that dumping and injury exist at the same time should not be sufficient to conclude that all injury is caused by dumping, nor is it appropriate to directly infer the level of injury from the amount of price undercutting, as is often done in practice. ${ }^{3}$ In addition, a number of studies show how strongly the practice of cumulating imports over countries for injury determination purposes has contributed to positive findings in antidumping investigations. ${ }^{38}$ It was proposed then that cumulation be eliminated or confined to cases where evidence

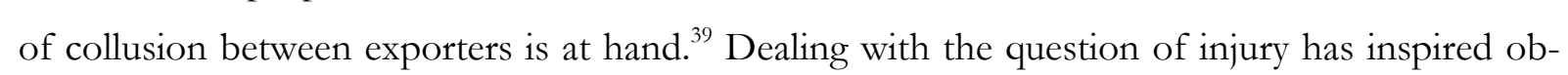
servers such as Finger (1998) to propose a "national interest clause", 4 which clearly goes beyond the hearing of interested parties provided for in the current Agreement. The clause would require a comparison of any injury incurred by import competing producers with the benefits for consumers arising from lower prices.

\section{Raising the attractiveness of the safeguard clause}

The second, less noted category of measures for reform aims at increasing the attractiveness of the safeguard clause. It is argued that a new safeguard regime could attract at least part of the contingent protection that is now handled under antidumping rules. Obviously, such attraction could be achieved by approaching antidumping along one of two axes in Figure 3, or along both of them: compensation could be reduced and/or prerequisites could be lowered. Steps in the first direction were actually taken within the framework of the Uruguay Round. An important result from this perspective was the suspension of the compensation requirement for a three-year time period in case of absolutely increasing imports. Yet, there are observers who would like to go even further by completely getting rid of compensation. 1

\footnotetext{
See Hoekman and Mavroidis (1996).

See Didier (2001) and Tharakan (1999a).

See Prusa (1998), Tharakan, Greenaway and Tharakan (1998), or Hansen and Prusa (1996).

See Didier (2001), Messerlin (2000), or Tharakan (1999a).

Synonymous would be a mandated "cost-benefit analysis" of antidumping measures, see Bronckers (1996).

41 See e.g. Hoekman and Leidy (1989). Actually, the compensation component of the safeguard clause fell in disgrace long ago. Tumlir (1974) considered that "Article XIX is, at one and the same time, too exacting and too lenient." (p. 262) Whereas "lenient" refers to the fact that temporary protection could become permanent, the requirement to compensate is "too exacting". In this spirit, Robertson (1992) is convinced that "[r]eciprocity has no place in dealing with temporary emergency actions if they are properly supervised." (p. 47). Bown (2002), who is rather sceptical about reforming the current Agreement on Safeguards, considers (without sympathy) shifting to-
} 
As to lowering the prerequisites of the safeguard clause, we are not aware of any substantial proposals. ${ }^{2}$ Messerlin and Tharakan (1999) consider how to improve the determination of serious injury by using a better proxy or by increasing transparency. But their aim is to achieve a more homogenous procedure, and not to raise the number of circumstances where the safeguard clause may be used. Nevertheless, it is evident that the attractiveness of the safeguard clause could be raised dramatically if the number of prerequisites to be fulfilled was reduced. Messerlin (2000) argues that the Uruguay Round relaxed the prerequisite requiring ongoing liberalisation as the cause for import surges, since Article 2.1 of the Agreement on Safeguards does not mention it anymore. The same is true for unforeseen developments. However, although this omission makes the two prerequisites somewhat more ambiguous, there is in principle no reason to assume that they have lost their validity.

Summarising the analysis above, we note that the existing suggestions for reform pursue two directions, as shown by the arrows in figure 4: raising the level of prerequisites for antidumping, and less vigorously, reducing the amount of compensation for safeguard clause measures. These directions seem to indicate that the optimal instrument for temporary import restrictions must be found in the upper-left region of the plain.

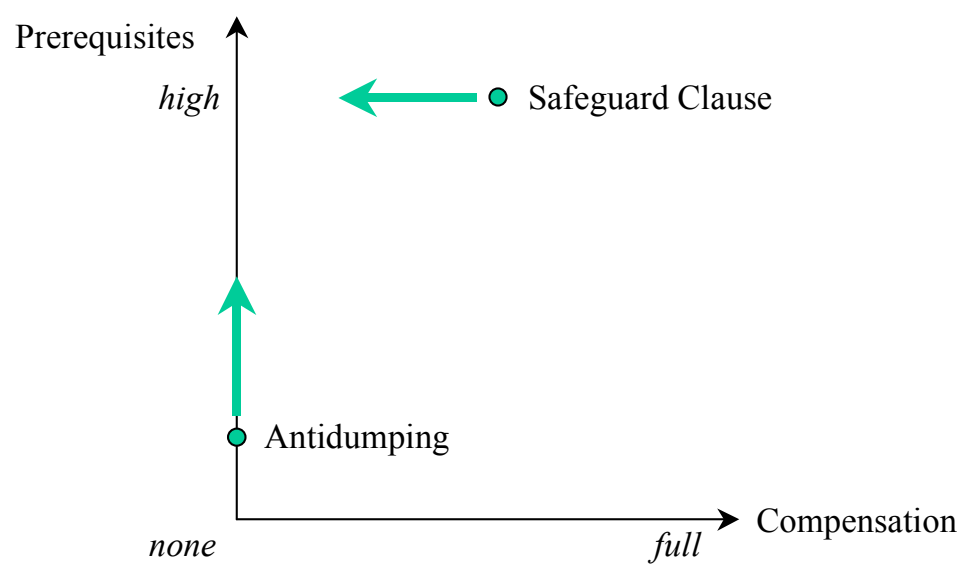

Figure 4: Directions of existing suggestions for reform

wards a regime where countries using the safeguard clause are compensated themselves by trading partners. This might support the adjustment process.

42 In contrast, there have been suggestions to raise the level of prerequisites. See e.g. Lee and Mah (1998), who want the Agreement to specify that imports must be the "major" cause for injury or threat thereof.

43 In both Argentina - Safeguard Measures on Imports of Footwear (WT/DS121) and Korea - Definitive Safeguard Measure on Imports of Certain Dairy Products (WT/DS98), the Appellate Body explicitly refers to "unforeseen" circumstances. See para. 94 and para. 87, respectively. In US - Safeguard Measures on Imports of Fresh, Chilled, Frozen Lamb Meat from New Zealand and Australia (WT/DS178), it emphasises the full and continuing applicability of Article XIX GATT (para. 70). The Appellate Body is criticised for this attitude in Lee (2001). 


\section{Impact on current negotiations}

The existing suggestions relating to the prerequisites of antidumping have experienced some repercussions in recent multilateral consultations about modification of the current regime. This becomes obvious when reading the relevant passage in the Declaration passed at the Forth Ministerial Conference of the WTO in Doha in November 2001:

\footnotetext{
"In light of experience and of the increasing application of these instruments by Members, we agree to negotiations aimed at clarifying and improving disciplines under [the Agreement on Antidumping], while preserving the basic concepts, principles and effectiveness of [this Agreement] and [its] instruments and objectives [...].
}

The declaration emphasises the preservation of basic concepts, principles and effectiveness of the current antidumping regime. It thereby makes clear that nothing should be expected with regard to a changed appraisal of antidumping, but rather that future negotiations are likely to continue what was started at the occasion of the Uruguay Round: attempting to reverse the negative consequences of the Tokyo Round Antidumping Code by gradually raising the level of prerequisites.

However, as the numbers in section two have shown, the Uruguay Round was not successful in its attempt. The use of antidumping was not restrained, but rather became even more popular since then. Therefore, it is doubtful that a continued focus on higher prerequisites will be successful in the future. Two substantial risks of failure can be identified. The first one is a classical standstill of negotiations, as regularly experienced in the long history of multilateral trade liberalisation. Such a standstill would be provoked by governments recognising that they are asked to give up the high level of trade policy flexibility provided by the current antidumping rules. The consequence would be a perpetuation of today's regime. The second risk is very closely related, being that negotiations about higher prerequisites are prone to promote piecemeal (or "clause-byclause") changes of the existing agreement. Yet, an inherently wrong concept cannot effectively be overcome by slight amendments. Finger (1993) asserts that "[r]eform will not be found in the details of the antidumping code." The result of such efforts might be a new agreement, initially celebrated as a breakthrough, yet soon to be discovered as an ineffective body of rules.

The strong focus of existing suggestions on the prerequisites of antidumping reflects a neglect of trade policy flexibility. We argue in the following section that this neglect is inappropriate. It not only impairs the prospects for a successful restraint of antidumping, but also is based on the

44 Ministerial Declaration of the Forth Ministerial Conference, Doha, 9 - 14 November 2001, Document No. WT/MIN(01)/DEC/W/1, para. 28. 
questionable assumption that trade policy flexibility is necessarily at loggerheads with a low frequency of temporary import restrictions and a liberal world trading order. An alternative solution for antidumping reform is proposed, which is reconcilable with trade policy flexibility, and which introduces compensation as the natural counterpart of any import restricting measure.

\section{An alternative solution: trade policy flexibility subject to full compensation}

High prerequisites for a temporary import restriction are synonymous to limiting trade policy flexibility. Deviations from initial concessions are possible only in rare circumstances, and these circumstances are clearly defined once the respective international trade agreement is concluded. The analysis of the reasons for including flexibility mechanisms into an international trade agreement will demonstrate that it does not make sense to predefine the circumstances where a temporary import restriction may be applied.

\section{A. The motives behind trade policy flexibility}

It is expected that the government makes all trade policy decisions and thereby maximises its own objective function. The latter is influenced by both economic efficiency considerations and various interest groups. ${ }^{5}$ Economic efficiency denotes the achievement of any distributive outcome with a minimum of allocative distortion. Since import restrictions represent an inefficient tool for redistribution, $\frac{16}{6}$ economic efficiency considerations favour a liberal world trading order. Interest groups, in contrast, are assumed to represent import-competing industries only. They seek for protection in form of import restricting measures.

At first, one would suppose that an international trade agreement fully reflects the objective functions of all participating governments, since it would not be concluded otherwise. Deviating from initial concessions should therefore not be in the interest of any government. However, such thinking is misleading. There are two potential sources motivating a government to deviate from initial concessions. The first source is incomplete contracts. When the trade agreement is signed, the future development of many variables that influence the optimal trade policy of the government is unknown. Examples are the strength of individual interest groups, the relative weight that the government attaches to their support compared to economic efficiency considerations, the general economic climate, the election cycle, or technological advances. The trade agreement cannot be made contingent on the evolution of all these variables. From a government

45 Tharakan (1995), Grossman and Helpman (1994), and Finger, Hall and Nelson (1982) have introduced important political economy aspects of trade policy.

46 See Dixit (1985) for a broad treatment. 
perspective, it is therefore characterised by too much rigidity, i.e. the commitments are not sufficiently dependent on the future state of the world.

The second source that could motivate the government to deviate from its initial concessions is a lack of commitment at the time of concluding the trade agreement. The agreements supervised by the WTO cover an enormous field of trade (and related) topics and include at present 144 member countries. Negotiations in the run-up to the conclusion of the Uruguay Round were highly complex, and delegations finally came under considerable political pressure to achieve a successful result. It is very probable that some elements of the agreements remained contentious until the very last day of negotiation, and that they remained so even after the signing. The successful conclusion of the Uruguay Round was then an expression of the political will to reach an agreement on essential points. The contentious elements found their way into the agreement and might even have been given an unambiguous wording. Yet, at the same time, it might have been rather clear that some governments would not intend to stick to all of their concessions ${ }^{47}$.

How does the multilateral trading order deal with these potential sources for deviation? The inclusion of the safeguard clause into the GATT in 1947 manifestly expressed the conviction that the process of liberalising world trade would not be feasible unless a certain degree of trade policy flexibility existed, which would allow the government to respond to changes in the environment. It is now possible to argue that the safeguard clause wanted economic efficiency requirements - namely a smooth structural adjustment - to be the only reason for deviation. Therefore, the clause would not take into account any political motives, notably those responding to interest group pressure. As a consequence, the argument goes on, it was justified to predefine prerequisites that are exclusively based on economic efficiency criteria.

This argument, however, is not wholly convincing. It is extremely doubtful that the structural adjustment argument for the safeguard clause has any merits on economic efficiency grounds. First, the employment-displacement effects from liberalised trade are chronically exaggerated. Second, even in the case of a strong need for adjustment, there are more efficient ways of temporarily supporting ailing industries than the restriction of imports. ${ }^{9}$ Moreover, there is no guarantee that the safeguard clause actually promotes adjustment. The converse could be true. Finally,

47 The case EC - Measures Affecting Meat and Meat Products (WT/DS26) might be a good example: The EC accepted the relevant rules of the SPS agreement, due to its integration into the broad framework of the Uruguay Round, but there has obviously never been an intention to overturn the inconsistent policy of banning hormone-treated beef.

48 See e.g. Lawrence and Krugman (1993).

49 Government subsidies would be an example.

50 Kohler and Moore (2001) show in a model with asymmetric information about costs that the safeguard clause leads to under-adjustment. 
the need for adjustment not only arises because of an increasingly liberalised world trade. This need could also be attributed to changing consumer tastes, technology bringing about new production methods, or environmental concerns causing more stringent national regulation. In all these cases, temporary import restrictions might ease the pressure on import-competing industries. Thus, the question is: why should adjustment necessitated by rising imports be a justification for safeguards, whereas adjustment caused by other factors is not? $\square^{51}$ It is difficult to find a plausible answer, and therefore the following conclusion is drawn: since the safeguard clause can hardly be explained by economic efficiency reasoning, it follows that it is an instrument implicitly intended to provide flexibility on political grounds. Indeed, there are good reasons not to condemn political motives from the outset. After all, it is the government that concludes new international trade agreements, and which decides on the abandonment of already signed ones. Perceiving the constraints on trade policy flexibility as excessively tight, the government would simply refuse to initially make far-reaching concessions. Alternatively, it might later abandon a trade agreement in case of (unexpected) political stress. Both reactions can be assumed to have negative effects on economic efficiency. ${ }^{52}$

Once it is accepted that political motives should in principle suffice to enable the government to temporarily restrict imports, it is straightforward to recognise that the design of the safeguard clause is far from perfect. Although there is room for political manoeuvring in selected cases of rising imports, the prerequisites are not at all reconcilable with a broad spectrum of political motives arising independently of changing import levels, or of producer interests in general. ${ }^{3}$ Seemingly, the safeguard clause wants some political motives to potentially have an impact on trade policy, but prohibits others from having an equal effect. It is difficult to find logical reasons for such an arbitrary differentiation. It is therefore not surprising that many of those political motives, which could not be subsumed under the safeguard clause, sought for other channels, such as antidumping.

Antidumping, as currently applied, is more responsive to politically motivated import restrictions than the safeguard clause. On the one hand, this has much to do with the entirely missing compensation component and the possibility to disguise the protectionist intent by claiming the reestablishment of fair trade. However, on the other hand, the extensive use of antidumping has only been possible due to the modest prerequisites that come along with it. Despite significant

51 Jackson (1997), p. 176, brought up this question.

52 The argument is further elaborated on in Hauser and Roitinger (2002). It is in contrast to the popular perception that international trade agreements are first and foremost a tool to deprive the self-interested government from trade policy flexibility in order to make it resistant in face of interest group pressure. See e.g. Hauser (1986).

53 A prominent example is the widespread rejection of hormone-treated beef in Europe, which rather touches consumer than producer interests and could (therefore) never be handled by the safeguard clause. 
reductions of the compensation requirement introduced by the Agreement on Safeguards, there has been no observable shift from antidumping towards contingent protection under the safeguard clause, which is at least partly explained by the unaltered relative level of prerequisites.

\section{B. Full compensation instead of high prerequisites}

Isolated attempts to restrict the number of circumstances where antidumping may be applied are diametrically opposed to appreciating the political motives identified above. Yet, this is only one critical aspect of the existing suggestions for reform. In addition, the continued absence of full compensation as a natural counterpart of any import restricting measure is almost certainly the recipe for excessive use on world-wide scale. It translates into externalising costs on trading partners and will regularly provoke harsh reactions. Assuming that the government is not ready to sacrifice its trade policy flexibility, yet being equally aware that the costs of temporary import restrictions must not be externalised because of efficiency considerations, an alternative solution emerges: a trade policy instrument that has no prerequisites, but provides full compensation.

It is important to recognise that the function of full compensation is twofold. First, affected trading partners, represented by their governments, are made approximately as well off as they had been before the temporary import restriction was introduced. Second, full compensation replicates to a certain extent the effect of high prerequisites: the government is dissuaded from restricting imports whenever the political gains from deviation are lower than the political costs of full compensation. However, there are two fundamental differences in this respect. First, full compensation preserves the trade policy flexibility that would be lost in case of high prerequisites. The government is able respond to interest group pressure without having to reconsider participation in the international trade agreement. The second difference is that compensation should have a dampening effect on interest group activism, again in contrast to prerequisites. Thinking about concepts such as dumping, injury, causal effect, unforeseen developments and the like, lobbying in the presence of prerequisites is much about convincing the government that the current situation represents a state of the world fitting exactly into the corset construed by these prerequisites. Taking into account the information asymmetries to the disadvantage of the government, and the virtual absence of countervailing interests at the negotiation table, it is conceivable that interest groups have an easy time seeking protection of their respective markets. ${ }^{4.4}$

54 Robertson (1992), referring to the injury prerequisite of the safeguard clause, confirms that "[...] the determination of serious injury is often based on domestic political pressures, not on economic analysis." (p. 43) Our conclusion is further underlined in antidumping practice by the fact that foreign exporters often have to comply with "extremely complex information requirements" whenever they want to defend their case - and then still risk that their information is not taken into account, see Niels (2000), p. 480. Anecdotal evidence is provided by Bovard (1991). 
This conclusion becomes all the more plausible when considering the payoff structure for the government. The introduction of import restricting measures leads to political gains in terms of support from interest groups. Political costs, however, are modest as long as economic efficiency has a low weight in the government's objective function.

The situation is very different if compensation becomes an inseparable element of contingent protection. Even though interest groups are assumed to represent import-competing industries only, there is no unequivocal advocacy for import restricting measures anymore, since some industries would be affected by better market access for foreign exporters due to the compensation requirement. As a consequence, the political costs of an import restricting measure can easily exceed the political gains for the government. The number of import restrictions should therefore decrease significantly. Furthermore, any actual import restriction does not necessarily impair economic efficiency considerations, since it is accompanied by a market opening in another sector.

\section{Implementing the alternative solution}

The existing suggestions for reform of antidumping focus either on antidumping itself or on the safeguard clause. As figure 5 indicates, the alternative solution outlined above could also pursue two different directions. The first is to maintain antidumping, but to combine it with full compensation. Although conceptually interesting, it will be shown that such a combination is not promising. In contrast, the second direction merits considerable attention. It envisages the abolition of antidumping, supplemented by two modifications of the safeguard clause: a removal of prerequisites and an elimination of the exception to the full compensation requirement. It will be quite interesting to see that this suggestion is much less revolutionary in the context of the multilateral trading framework than one might expect.

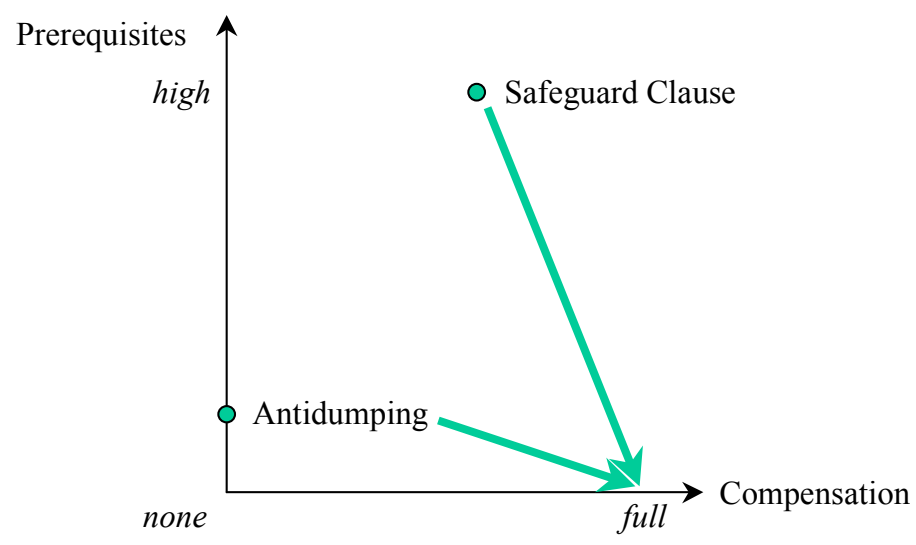

Figure 5: Directions for the implementation of the alternative solution 


\section{A. Antidumping with compensation}

As noted in section three, existing suggestions for reform have not intended to make antidumping contingent on the provision of compensation. This is hardly astonishing, since the alleged connection between antidumping and unfair trade is not reconcilable with the compensation of affected parties. Before proposing compensation, it would be necessary to get rid of the unfair trading argument. However, this would deprive antidumping of its most important justification.

That being said, it must be recognised that measures against alleged dumping were actually accompanied by compensatory effects on several occasions in the past. This was the case whenever antidumping investigations were terminated by a "voluntary price undertaking", which was imposed instead of antidumping duties. Such an undertaking helps to restrict imports of the good in question, but shifts rents to the foreign exporter by raising export prices. It is a form of managed trade admissible under the Agreement on Antidumping.

When considering these compensatory effects in light of our call for full compensation as formulated in the previous section, some remarks are important. To begin with, these effects are an outgrowth of abandoned investigations, not a feature of antidumping itself. Furthermore, they run counter to the aim of banning voluntary export restraints (VERs) stipulated by the Agreement on Safeguards, thereby creating an inconsistency in the world trading order. Most important, however, is the observation that such compensatory effects cannot fulfil the function of dissuading a government from excessively using the threat of antidumping. This rent-shifting does not provoke resistance of those import-competing interest groups that would be affected under "ordinary" compensation in form of market access concessions. Consequently, it comes without substantial political costs. But as shown, such political costs are a precondition for a restrained use of import restricting measures.

\section{B. A revised safeguard clause}

The idea of restraining antidumping action by a more attractive safeguard clause is not new, as shown in section three. However, we are not aware of any proposal that considers a reduction let alone an elimination - of prerequisites for the purpose of raising its attractiveness. The prerequisites of the safeguard clause appear to be sacrosanct. This is problematic for two reasons. On the one hand, it was argued that their selection reflects considerable arbitrariness and can

55 Bown (2002) indicates a second method of rent-shifting practised in the context of antidumping. In many instances of formal trade disputes concerning antidumping measures, the defendant evaded a Dispute Settlement Body Ruling (and its potential consequences) by withdrawing the antidumping measure and refunding the collected duties. 
hardly be based on sound economic reasoning. On the other hand, it was demonstrated that prerequisites are in general a questionable component of contingent protection.

In order to implement the alternative solution considered in section four, antidumping could be removed, and a revised safeguard clause could be introduced. The clause would not make temporary import restrictions dependent on any prerequisite, yet would require full compensation without exception. What would be the main implications? First, the safeguard clause would lose its current producer bias. If injury to import-competing industries were not a prerequisite anymore, other interest groups (such as consumers or environmentalists) would also be able to apply for temporary import restrictions. Terminating the privileged status of producers might quiet some of the most pronounced voices against globalisation. Furthermore, it could stimulate the debate within WTO member states on how to find a more equitable balance between opposing national interests. Second, the exception to the full compensation requirement in case of absolutely rising imports would cease to exist. This is not necessarily a loss, considering that the exception enables free-riding for three years and allows a belated change of the negotiated market access balance between WTO members. Third, no WTO member would be impeded to combat predatory pricing. Anticompetitive behaviour, if indeed present in international trade relations, could be handled well enough by national antitrust policy, supported by positive comity. Fourth, the main merits of the revised safeguard clause can be inferred directly from the analysis in section four. In contrast to existing suggestions for reform, the revised clause makes it possible to abolish antidumping without impairing trade policy flexibility. Yet, due to its full compensation requirement, the clause effectively restrains protectionist behaviour.

It might seem revolutionary to introduce a trade policy instrument that makes possible a temporary deviation from initial concessions without any prerequisite. However, the multilateral trading framework already disposes of a similar mechanism. Every WTO member is able to restrict imports by violating a WTO agreement and by undergoing the dispute settlement procedure stipulated in the Dispute Settlement Understanding (DSU). Obviously, the violation does not depend on any prerequisite. Between 1 January 1995 and 14 June 2002, 260 complaints about alleged violations of an agreement were notified to the WTO ${ }^{5}$ This led to 60 adopted panel and Appellate Body reports. A large majority of them ended in favour of the complainant, which indicates that violations are normally not caused by legal uncertainty, but by intentional deviation from initial concessions. Members of the GATT - and later of the WTO - have never attempted to make all possible efforts in order to prevent any violation of an agreement. This can most easily

56 See the Update of WTO Dispute Settlement Cases, prepared by the WTO Secretariat, 21 June 2002, Document No. $\mathrm{WT} / \mathrm{DS} / \mathrm{OV} / 7$. 
be seen when looking at the enforcement mechanism. Of course, there are always natural limits of enforcement, since sovereign countries cannot be forced to behave in a particular way as long as drastic measures (such as military intervention) remain excluded. However, it can be argued that the WTO members have consciously introduced much stricter limits of enforcement, which clearly fall short of what would be possible among sovereign states. The strongest indication for this claim is found in the DSU itself. Its references to retaliatory measures have no punitive character and are inspired by the attempt to restore the initial balance of concessions. Article 22:4 reads: "The level of the suspension of concessions or other obligations authorised by the DSB shall be equivalent to the level of the nullification or impairment." Retaliation is thereby strictly limited in scope and duration. Most interestingly, there is a complete absence of any threat that membership is suspended in case of non-compliance.

Although the violation of a WTO agreement is a mechanism that enables import restrictions without fulfilling any prerequisite, it must be clearly distinguished from a deviation under the revised safeguard clause. Despite weak enforcement mechanisms, a violation represents illegal behaviour. In contrast, a temporary import restriction under the revised safeguard clause would be perfectly in accordance with WTO law, as long as full compensation is provided.

\section{The role of the DSU under the revised safeguard clause}

Under the revised safeguard clause, the DSU does not intend to deter import restrictions per se. Instead, its primary task would be to ensure that any temporary import restriction comes along with full compensation. As mentioned, full compensation should set in at the same time that the import restriction is imposed.

Two different dispute scenarios can be distinguished. In a first scenario, the defendant government does not deny an alleged import restriction under the clause, but no agreement about the nature of full compensation can be found. In this case, an arbitrator could assume the task of settling the dispute by making a binding decision. In a second scenario, the defendant denies the allegation that imports have been restricted. In reaction to this denial, the complainant government follows the procedure outlined in the DSU. If no mutually accepted solution can be found in advance, the DSB will adopt the report issued by a panel (or by the Appellate Body). Both panels and the Appellate Body generally refrained from making specific suggestions in the past. If the alleged deviation from initial concessions was confirmed, they just recommended that the defendant bring the respective measure into conformity with its obligations under the WTO agreements. Such a recommendation has a fundamentally changed meaning under the revised 
safeguard clause: "conformity" would explicitly include the provision of full compensation. Therefore, the defendant government would have free choice among two alternative ways of compliance. The first alternative is to withdraw the import restricting measure. In spite of such a withdrawal, retrospective compensation for past losses should be owed in order to prevent free riding. $\square^{58}$ The second alternative for the defendant is to maintain the import restriction, and to compensate affected trading partners for all past and future losses. If no agreement about the nature of full compensation is achieved, an arbitrator would again make a binding decision.

\section{Conclusion}

Existing suggestions for the reform of antidumping intend to restrain antidumping by raising the prerequisites for its use. Such a restraint would be welcome, but the focus on higher prerequisites is neither necessary nor promising in order to promote a liberal world trading order. It is not necessary because the aim of keeping the number of temporary import restrictions low can also be achieved by combining trade policy flexibility with the provision of full compensation. There are good reasons to believe that compensation does even a better job than prerequisites in this regard. Attempting to raise the prerequisites for antidumping is not promising, because the government cannot be expected to sacrifice its trade policy flexibility. The Uruguay Round Agreement on Antidumping once again frustrated any such illusions. Furthermore, an externalisation of costs cannot be excluded with high prerequisites, as long as compensation is not required. This impairs the relationship among trading partners.

This article has proposed to abolish antidumping and to introduce a revised safeguard clause. This clause maintains the trade policy flexibility inherent in the current Agreement on Antidumping. Governments would continue to have discretion on when to restrict imports, because no prerequisites need to be fulfilled. At the same time, it has been shown that the requirement of full compensation effectively restrains protectionist behaviour, because import-competing industries would lose their unequivocal bias against a liberal world trading order.

57 See Pauwelyn (2000).

58 Retrospective compensation was rare in the past. It is difficult to implement. For a discussion see Rosas (2001). 


\section{Bibliography}

Blonigen, B.A. and Bown, C.P. (2001): Antidumping and Retaliation Threats. NBER Working Papers, No. 8576.

Blonigen, B.A. and Prusa, T.J. (2001): Antidumping. NBER Working Papers, No. 8398.

Boscheck, R. (2001): The Governance of Global Market Relations: The Case of Substituting Antitrust for Antidumping. World Competition, Vol. 24, No. 1, pp. 41-64.

Bovard, J. (1991): The Fair Trade Frand. New York.

Bown, C.P. (2002): Why are safeguards under the WTO so unpopular? World Trade Review, Vol. 1, No. 1, pp. 47-62.

(2001): On the Economic Success of GATT/WTO Dispute Settlement, mimeo, December.

Bronckers, M.C.E.J. (1996): Rehabilitating Antidumping and other Trade Remedies through Cost-Benefit-Analyses. Journal of World Trade, Vol. 30, No. 2, pp.5-37.

Bütler, M. and Hauser, H. (2000): The WTO Dispute Settlement System: A First Assessment from an Economic Perspective. The Journal of Law, Economics, \& Organisation, Vol. 16, No. 2, pp. 503-33.

Corden, M.W. (1997): Trade policy and economic welfare. Oxford.

Didier, P. (2001): The WTO Anti-Dumping Code and EC Practice. Issues for Review in Trade Negotiations. Journal of World Trade, Vol. 35, No. 1, pp. 33-54.

Dixit, A.K. (1985): Tax policy in open economies. In: Auerbach, A.J. and Feldstein, M. (eds.): Handbook of public economics. Vol. I. North Holland.

Finger, J.M. (1998): GATT experience with safeguards. World Bank Working Papers, No. 2000. (1993): Reform. In: Finger (ed.): Antidumping - How It Works and Who Gets Hurt. Ann Arbor, pp. 57-79.

, Hall, H.K. and Nelson, D.R. (1982): The Political Economy of Administered Protection. American Economic Review, Vol. 72, No. 3, pp. 452-66.

Friedmann, D. (1989): The Efficient Breach Fallacy. Journal of Legal Studies, Vol. 18, pp. 1-24. 
Gallaway, M.P., Blonigen, B.A. and Flynn, J.E. (1999): Welfare costs of the U.S. antidumping and countervailing duty laws. Journal of International Economics, Vol. 49, No. 2, pp. 211-44.

Grossman, G.M. and Helpman, E. (1994): Protection for Sale. American Economic Review, Vol. 84, No. 4, pp. 833-50.

Hansen, W.L. and Prusa, T.J. (1996): Cumulation and ITC Decision-Making: The Sum of the Parts is Greater than the Whole. Economic Inquiry, Vol. 34, No. 4, pp. 746-69.

Hauser, H. (1986): Domestic Policy Foundation and Domestic Policy Function of International Trade Rules. Aussenwirtschaft, Vol. 41, No. II/III, pp. 171-84.

and Roitinger, A. (2002): A Renegotiation Perspective on Transatlantic Trade Disputes. Discussion Paper No. 2002-09, University of St. Gallen, Department of Economics.

and Schöne, R. (1994): Is there a Need for International Competition Rules? Aussenwirtschaft, Vol. 49, No. II/III.

Hindley, B. (1993): Antidumping Action and the EC: A Wider Perspective. In: Hilf, M. and Petersmann, E.-U. (eds.): National constitutions and International Economic Law. Kluwer, pp. 371-90.

Hoekman, B.M. (1998): Free Trade and Deep Integration: Antidumping and Antitrust in Regional Agreements. World Bank Working Papers, No. 1950, July.

and Leidy, M.P. (1989): Dumping, Antidumping and Emergency Protection. Journal of World Trade, Vol. 23, No. 5, pp. 27-44.

and Mavroidis, P.C. (1996): Dumping, Antidumping and Antitrust. Journal of World Trade, Vol. 30, No. 1, pp. 27-52.

Horlick, G.N. and Shea, E.C. (1995): The World Trade Organization Antidumping Agreement. Journal of World Trade, Vol. 29, No. 1, pp.5-31.

Jackson, J.H. (1997): The World Trading System: Law and Policy of International Economic Relations. $2^{\text {nd }}$ Ed. MIT Press.

Kim, J.B. (2002): Fair Price Comparison in the WTO Anti-dumping Agreement. Journal of World Trade, Vol. 36, No. 1, pp. 39-56. 
Kohler, P. and Moore, M.O. (2001): The Safeguard Clause, Asymmetric Information, and Endogenous Protection. Review of International Economics, Vol. 9, No. 1, pp. $67 \mathrm{ff}$.

Krishna, R. (1997): Antidumping in Law and Practice. World Bank Working Papers, No. 1823, September.

Kydland, F.E. and Prescott, E.C. (1977): Rules rather than discretion: The inconsistency of optimal plans. Journal of Political Economy, Vol. 85, No. 3, pp. 473-91.

Lawrence, R. and Krugman P. (1993): Trade, Jobs, and Wages. NBER Working Paper, No. 4478.

Lee, Y.-S. (2001): Destabilization of the Discipline on Safeguards? Inherent Problems with the Continuing Application of Article XIX after the Settlement of the Agreement on Safeguards. Journal of World Trade, Vol. 35, No. 6, pp. 1235-46.

and Mah, J.S. (1998): Reflections on the Agreement on Safeguards in the WTO. World Competition, Vol. 21, No. 6, pp. 25-31.

Lindsey, B. (2000): The U.S. Antidumping Law - Rhetoric versus Reality. Journal of World Trade, Vol. 34, No. 1, pp. 1-38.

Lipstein, R.A. (1997): Using antitrust principles to reform antidumping law. In: Graham, E.M. and Richardson, J.D. (eds.): Global Competition Policies. Institute for International Studies, pp. 40538.

Mavroidis, P.C. and Van Siclen, S.J. (1997): The Application of the GATT/WTO Dispute Resolution System to Competition Issues. Journal of World Trade, Vol. 31, No. 5, pp. 5-45.

Messerlin, P.A. (2001): Measuring the Costs of Protection in Europe. European Commercial Policy in the 2000s. Washington DC.

(2000): Antidumping and Safeguards. In: Schott, J.J. (ed.): The WTO After Seattle. Washington DC, pp. 159-83.

(1994): Should Antidumping Rules Be Replaced by National or International Competition Rules? Aussenwirtschaft, Vol. 49, No. 2/3, pp. 351-73.

and Tharakan, P.K.M (1999): The Question of Contingent Protection. The World Economy, Vol. 22, No. 9. 
Miranda, J., Torres, R.A. and Ruiz, M. (1998): The International Use of Antidumping: 1987-1997. Journal of World Trade, Vol. 32, No. 5, pp. 5-71.

Morgan, C. (1996): Competition Policy and Anti-Dumping - Is it Time for a Reality Check? Journal of World Trade, Vol. 30, No. 5, pp. 61-88.

Niels, G. (2000): What Is Antidumping Policy Really About? Journal of Economic Surveys, Vol. 14, No. 4, pp. 467-92.

Palmeter, D. (1996): A Commentary on the WTO Anti-Dumping Code. Journal of World Trade, Vol. 30, No. 4, pp. 43-69.

Pauwels, W., Vandenbussche, H. and Weverbergh, M. (2001): Strategic Behaviour under European Antidumping Duties. International Journal of the Economics of Business, Vol. 8, No. 1, pp. 75-99.

Pauwelyn, J. (2000): Enforcement and Countermeasures in the WTO: Rules are Rules - Toward a More Collective Approach. The American Journal of International Law, Vol. 94, pp. 335-47.

Prusa, T.J. (1999): On the Spread and Impact of Antidumping. NBER Working Paper, No. 7404. (1998): Cumulation and Antidumping: A Challenge to Competition. The World Economy, Vol. 21, No. 8, pp. 1021-33.

(1992): Why Are So Many Antidumping Petitions Withdrawn? Journal of International Economics, Vol. 33, pp. 1-20.

Robertson, D. (1992): GATT Rules for Emergency Protection. Harvester Wheatsheaf.

Rosas, A. (2001): Implementation and Enforcement of WTO Dispute Settlement Findings: An EU Perspective. Journal of International Economic Law, Vol. 4, No. 1, pp. 131-44.

Shin, H.J. (1998): Possible Instances of Predatory Pricing in Recent U.S. Antidumping Cases. In: Lawrence, R.Z. (ed.): Brookings Trade Forum 1998, pp. 81-97.

Stewart, T.P. (1991): Administration of the Antidumping Law: A Different Perspective. In: Boltuck, R. and Litan, R.E. (eds.): Down in the Dumps: Administration of the Unfair Trade Laws. Washington DC, pp. 288-330. 
Sykes, A.O. (2000): The Remedy for Breach of Obligations under the WTO Dispute Settlement Understanding: Damages or Specific Performance? In: Bronckers, M. and Quick, R. (eds.): New Directions in International Economic Law. Kluwer Law International, pp. 347-57.

Taylor, C.T. (2001): The Economic Effects of Withdrawn Antidumping Investigations: Is There Evidence of Collusive Settlements. FTC Bureau of Economics Working Papers, No. 240.

Tharakan, P.K.M. (1999): Predatory Pricing and Anti-dumping. In: Norman, G. and Thisse, J.-F. (eds.): Market Structure and Competition Policy, Cambridge University Press. (1999a): Is Anti-Dumping Here to Stay? The World Economy, Vol. 22, No. 2, pp. 179206. (1995): Political economy and contingent protection. The Economic Journal, Vol. 105, pp. 1550-64.

, Greenaway, G. and Tharakan, J. (1998): Cumulation and Injury Determination of the European Community in Antidumping Cases. Weltwirtschaftliches Archiv, Vol. 134, No. 2, pp. 320-39.

, Vermulst, E. and Tharakan, J. (1998): Interface Between Anti-Dumping Policy and Competition Policy: A Case Study. The World Economy, Vol. 21, No. 8, pp. 1035-60.

Trachtman, J. (2002): Who's Right Is It Anyway? Private Parties in EC-US Dispute Settlement at the WTO. Paper presented at the Conference on Dispute Prevention and Dispute Settlement in the Transatlantic Partnership, Florence, 3 May 2002.

Trebilcock, M.J. and Howse, R. (1999): The Regulation of International Trade, Second Ed., Routledge.

Tumlir, J. (1974): Emergency Protection against Sharp Increases in Imports. In: Corbet, H. and Jackson, R. (eds.): In Search of a New World Economic Order, London.

Vermulst, E. (1997): Adopting and Implementing Anti-Dumping Laws - Some Suggestions for Developing Countries. Journal of World Trade, Vol. 31, No. 2, pp. 5-23.

WTO (1995): Analytical Index: Guide to GATT Law and Practice. Vol. II, Geneva. 